\title{
PENGARUH INDEKS BURSA REGIONAL TERHADAP INDEKS HARGA SAHAM GABUNGAN (IHSG)
}

\author{
Margarita Ekadjaja \\ Fakultas Ekonomi Universitas Tarumanagara, Indonesia \\ e-mail: rita_e11510@yahoo.com
}

\begin{abstract}
In relation with fast economical growth in Indonesia and followed by the growth of the stock exchange, investing in the stock exchange is become one of the profitable choices for the investor. The main indicator of Indonesian stock exchange performance is called IHSG. This research aiming to describe the correlation between regional index (STI Index and KLCI) and IHSG either simultaneously or partially in BEI. The samples used in this research is regional index during 2008-2012. Model of analysis used in this research is multiple regression analysis. Simultant used to test the influence from entire / all variable regional index to IHSG with significant level of 5\%. The research stated that, simultaneously there was a significanct correlation between regional Index (STI and KLCI) to IHSG the Fhitung > Ftabel $(326.4711>3,35)$. Partially there was significant correlation among STI and KLCI to IHSG and there was a significanct correlation among regional Index (STI and KLCI) to the IHSG the significancy in 5\%.
\end{abstract}

Keywords: stock exchange, regional index, IHSG, STI, KLCI

\begin{abstract}
Abstrak: Sejalan dengan pertumbuhan ekonomi yang pesat di Indonesia dan dengan perkembangan bursa saham, menjadikan investasi di bursa saham menjadi pilihan yang menguntungkan bagi penanam modal. Indikator utama dari bursa saham di Indonesia adalah IHSG. Penelitian ini bertujuan untuk menjabarkan hubungan antar indeks regional (Indeks STI dan KLCI) dan IHSG baik secara serempak maupun sebagian di Bursa Efek Indonesia. Sampel yang digunakan dalam penelitian ini adalah indeks regional selama tahun 2008-2012. Model dari analisa yang digunakan dalam penelitian ini adalah analisa regresi berganda. Simultan digunakan untuk menguji pengaruh dari keseluruhan variabel indeks regional terhadap IHSG dengan tingkat signifikansi 5\%. Hasil penelitian menunjukkan secara serempak terdapat hubungan yang jelas antara indeks regional (STI dan KLCI) terhadap IHSG. Fhitung > Ftabel (326.4711 > 3,35). Secara sebagian terdapat hubungan yang jelas antara STI dan KLCI terhadap IHSG dan terdapat hubungan yang jelas antara indeks regional (ST(I dan KLCI) terhadap IHSG dengan tingkat signifikansi $5 \%$
\end{abstract}

Kata kunci: bursa saham, indeks regional, IHSG, STI, KLCI

\section{PENDAHULUAN}

Sejalan dengan perkembangan ekonomi Indonesia yang telah berkembang dengan pesat dan diikuti dengan perkembangan bursa efek. Maka, bursa efek dapat menjadi salah satu sarana investasi yang menguntungkan. Surat berharga yang di perdagangkan di bursa efek adalah saham biasa, saham preferen, obligasi, obligasi konversi, sertifikat right, waran. Dengan meningkatnya jumlah perusahaan yang terdaftar di Bursa Efek Indonesia 
(BEI) dan didukung kinerja keuangan perusahaan yang semakin solid dapat meningkatkan kepercayaan investor. Indikator utama kinerja pasar modal adalah Indeks Harga Saham Gabungan (IHSG) yang menunjukkan perubahan nilai dari seluruh saham yang terdaftar telah mendorong bursa saham regional untuk terus bergerak menguat.

Pengaruh pergerakan Indeks Harga Saham Gabungan (IHSG) BEI dapat dipengaruhi oleh beberapa faktor seperti masuknya dana asing yang berinvestasi pada IHSG dikarenakan melemahnya nilai tukar mata uang suatu negara, pemilihan Presiden RI. Telah terbukti secara empiris bahwa ada kausalitas dua arah antara exchange rate dan stock price sebelum terjadi krisis keuangan di asia, namun setelah krisis exchange rate mempengaruhi stock price (Azman,et.al, 2002). Peningkatan nilai tukar dan krisis pasar modal inilah yang menimbulkan pertanyaan tentang hubungan potensial antara keduanya. Faktor lain adalah pengaruh perubahan bursa regional terhadap sikap investor di Indonesia sehingga mempengaruhi pergerakan indeks, hal ini didasarkan pada kondisi pasar yang lemah akibat isu dari kondisi bursa regional sehingga terlihat mudah sekali isu bursa regional mempengaruhi indeks.

Kenaikan indeks harga saham BEI juga tidak lepas dari membaiknya indikator ekonomi Indonesia, seperti rendahnya laju inflasi yang mencapai $4,45 \%$ berdasarkan situs BI dan di dorong oleh tindakan Bank Indonesia yang konsisten menurunkan suku bunga secara agresif yang mencapai 6,75\% per tanggal 17 Maret 2016. Selain itu, dapat juga di pengaruhi oleh pergerakan bursa-bursa regional seperti Malaysia, Singapura, Hongkong, Jepang, dan Thailand.

Pasar modal Indonesia melalui bursa efek Indonesia merupakan bagian tak terpisahkan dari kegiatan bursa saham regional. Bursa saham yang lokasinya berdekatan, seringkali memiliki investor yang sama. Fenomena yang terjadi karena globalisasi serta Indonesia sebagai anggota World Trade Organization telah membuka bursa saham bagi invetor asing yang berinvestasi diseluruh dunia. Oleh karena itu, perubahan di satu bursa juga akan ditransmisikan ke bursa Negara lain. Dalam hal ini, biasanya bursa yang lebih besar akan mempengaruhi bursa yang lebih kecil. Penelitian sebelumnya dilakukan oleh Noer (2000) tentang bagaimana bursa merespon terhadap shock dari bursa lain, apabila terjadi shock di Amerika Serikat maka bursa-bursa regional tidak akan terlalu meresponnya. Hanya di Singapura, Hong Kong, Jepang dan Taiwan dan New Zealand yang akan langsung merespon, dan respon pun tidak cukup besar. Sebaliknya jika shock di Singapura, Australia atau Hong Kong, secara cepat shock tersebut akan ditransmisikan ke hampir semua bursa saham di Asia Pasifik, termasuk BEI.

Dalam penelitian ini, penulis memilih Bursa Efek Indonesia , Bursa Malaysia, dan Bursa Singapura sebagai obyek penelitian, karena ketiga bursa ini yang memiliki letak geografis terdekat dengan wilayah Indonesia (IHSG) dan termasuk dalam wilayah Asia Timur. Sehingga dapat melihat pergerakan Indeks Harga Saham Gabungan (IHSG) BEJ yang dipengaruhi oleh Kuala Lumpur Composite Index (KLCI), Straits Times Index (STI). Dengan dilakukan penelitian ini diharapkan dapat mengetahui waktu yang tepat untuk melakukan transaksi terhadap Indeks Harga Saham Gabungan.

Berdasarkan uraian di atas, maka permasalahan dalam penelitian adalah: (1) Apakah indeks bursa Malaysia dan indeks bursa Singapura berpengaruh secara simultan terhadap pergerakan IHSG?; (2) Apakah indeks bursa Malaysia dan indeks bursa Singapura berpengaruh secara parsial terhadap pergerakan IHSG?; (3) Berapa besar korelasi indeks bursa Malaysia dan indeks bursa Singapura terhadap IHSG BEI ? 
Adapun tujuan dari penelitian ini adalah: (1) Agar investor dapat menentukan waktu kapan harus berinvestasi dan kapan harus dihentikan; (2) Dapat mengenal lebih jauh mengenai indeks-indeks yang ada di dalam maupun di luar negeri; (3) Investor dapat mengetahui bagaimana kinerja bursa saham; (4) Mengetahui pengaruh bursa regional terhadap pergerakan Indeks Harga Saham Gabungan (IHSG) BEI.

\section{KAJIAN TEORI}

Menurut Dahlan Siamat (2005) dalam Kamus Pasar Uang dan Modal, pasar modal adalah pasar kongkret atau abstrak yang mempertemukan pihak yang menawarkan dan yang memerlukan dana jangka panjang, yaitu jangka satu tahun keatas. Abstrak yang dimaksud yaitu transaksi yang dilakukan memalui mekanisme over the counter (OTC). Menurut David L.Scott (2009), pasar modal adalah pasar untuk dana jangka panjang dimana saham biasa, saham preferen dan obligasi diperdagangkan. Menurut Suad Husnan (2005), pasar modal (capital market) merupakan pasar untuk berbagai instrumen keuangan jangka panjang yang bisa diperjualbelikan, baik dalam bentuk utang ataupun modal sendiri.

Dari beberapa pengertian tersebut di atas mengenai pasar modal maka secara umum dapat diartikan sebagai tempat yang mempertemukan pihak penjual dan pembeli instrumen keuangan jangka panjang baik dalam bentuk utang manupun modal sendiri.

Surat Berharga. Menurut UU Pasar Modal No. 8 Tahun 1995 menyatakan bahwa surat berharga adalah surat pengakuan utang, surat berharga komersial, saham, obligasi, tanda bukti utang, unit penyertaan Kontrak Investasi Kolektif, kontrak berjangka atas efek, dan setiap derivatif dari efek. Yang termasuk dalam produk derivatif yaitu instrumen surat berharga yang harganya tergantung dari harga atau kinerja surat berharga pokoknya. Menurut Suad Husnan (2005) surat berharga atau sering disebut sekuritas merupakan secarik kertas yang menunjukkan hak pemodal (yaitu pihak yang memiliki kertas tersebut) untuk memperoleh bagian dari prospek atau kekayaan organisasi yang menerbitkan sekuritas tersebut dan berbagai kondisi yang memungkinkan pemodal tersebut menjalankan haknya.

Dari beberapa pengertian tersebut di atas maka secara umum surat berharga dapat diartikan dengan kepemilikan seseorang atau badan pada suatu perusahaan dimana pemegang saham tersebut memperoleh pembagian laba yang disebut deviden.

Menurut Suad Husnan (2005) macam-macam surat berharga yang di perdagangkan di Pasar Modal Indonesia yaitu: (1) Saham (Stock). Saham dapat didefinisikan sebagai tanda penyertaan atau pemilikan seseorang atau badan dalam suatu perusahaan; (2) Saham Preferen (Preferred Stock). Saham yang merupakan gabungan (hybrid) antara obligasi dan saham biasa. Artinya, disamping memiliki karakteristik seperti obligasi, juga memiliki karakteristik saham biasa; (3) Obligasi (Bond). Surat berharga atau sertifikat yang berisi kontrak antara pemberi pinjaman (dalam hal ini pemodal) dengan yang diberi pinjaman (emiten); (4) Obligasi Konversi (Convertible Bond). Hampir sama seperti obligasi biasa namun dalam obligasi ini terantum persyaratan untuk melakukan konversi. Persyaratan antara obligasi konversi satu dengan yang lain berbeda; (5) Right (Right). Merupakan hak bagi pemodal untuk membeli saham baru yang dikeluarkan emiten dan investor tidak terikat untuk membelinya karena hanya berupa hak saja; (6) Waran 
(Warrant). Yaitu hak untuk membeli saham biasa pada waktu dan harga yang sudah ditentukan.

Bursa Efek (Stock Exchange). Menurut situs Bursa Efek Indonesia, Bursa Efek adalah pihak yang menyelenggarakan dan menyediakan sistem atau sarana untuk perdagangan efek. Menurut Suad Husnan (2005), Bursa Efek adalah lembaga/perusahaan yang menyelenggarakan/menyediakan fasilitas sistem (pasar) untuk mempertemukan penawaran jual dan beli efek antar berbagai perusahaan/perorangan yang terlibat dengan tujuan memperdagangkan Efek perusahaan - perusahaan yang telah tercatat di bursa efek.

Menurut situs Blommberg, Bursa efek dapat dikelompokkan berdasarkan wilayah: (1) Bursa Efek Asia Timur: (a) Bagian Utara yaitu Jepang, Mongolia, Korea Utara, Korea Selatan, Cina, Hongkong, Taiwan; (b) Bagian Selatan yaitu Indonesia, Malaysia, Myanmar, Papua Wew Guinea, Filipina, Singapura, Thailand, Vietnam; (2) Bursa Efek Asia Selatan yaitu Bangladesh, Bhutan, India, Myanmar, Nepal, Pakistan, Sri Lanka.

Indeks Harga Saham. Menurut Suad Husnan (2005) Indeks harga saham merupakan tolak ukur utama yang menggambarkan pergerakan harga efek di pasar modal suatu negara. Harga saham yang digunakan dalam penghitungan indeks di bursa adalah harga saham yang terjadi di pasar regular. Menurut Afif (2010), Indeks Harga Saham sebenarnya merupakan angka Indeks Harga Saham yang telah disusun dan di hitung sedemikian rupa sehingga dapat dipergunakan untuk membandingkan kegiatan atau peristiwa, bisa berupa perubahan harga saham dari waktu ke waktu.

Angka Indeks Harga Saham adalah angka-angka yang menjadi ukuran situasi pasar modal, yang dapat digunakan untuk membandingkan peristiwa dan sebagai alat analisis. Kenaikan Indeks Harga Saham yang terus menerus menandakan bahwa pasar sedang bullish dan Indeks Harga Saham yang terus menerus menurun adalah indikator bahwa pasar sedang bearish. Indeks harga saham dapat ditemukan melalui beberapa cara: (1) Perkembangan Indeks Harga Saham Gabungan (IHSG) dapat di lihat pada halaman depan website pada bagian kanan atas, terdapat grafik pergerakan indeks selama 5 hari bursa; (2) Dapat pula mengamati indeks berjalan yaitu berupa ticker untuk semua jenis indeks pada saat tersebut. Untuk melihat indeks tersebut, klik market watch, dan beberapa saat kemudian muncul sebuah window yang berisi nilai indeks yang terus bergerak; (3) Dapat pula memperoleh nilai indeks historis selama 30 hari bursa dengan cara memilih menu informasi bursa pada bagian kiri halaman depan, selanjutnya pilih menu market index. Pada menu tersebut, dapat melihat nilai historis untuk semua jenis indeks selama 30 hari bursa; (4) Dapat pula memperoleh nilai indeks historis selama 2 tahun dengan cara memilih menu data perdagangan, selanjutnya pilih data harian, dan pilih market indices.

Menurut Afif (2010) Di Pasar Modal Indonesia indeks mempunyai beberapa fungsi antara lain: indikator tren pasar, indikator tingkat keuntungan, tolak ukur (benchmark) kinerja suatu portofolio, memfasilitasi pembentukan portofolio dengan strategi pasif, memfasilitasi berkembangnya produk derivative.

Metode penghitungan indeks menurut J.Supranto (2000): (1) Menghitung rata-rata hitung (arithmetic mean atau sering disebut mean saja) yaitu menghitung rata-rata harga saham yang masuk dalam anggota indeks bila mempunyai nilai variabel $\mathrm{X}$, sebagai hasil pengamatan atau observasi sebanyak N kali; (2) Menghitung rata-rata ukur (geometric mean) yaitu menghitung rata-rata indeks individual saham yang masuk dalam anggota indeks yang dapat digunakan sebagai ukuran; (3) Menghitung rata-rata tertimbang 
(weighted arithmetic mean) yaitu menghitung rata-rata nilai pasar saham yang masingmasing nilai mempunyai bobot/timbangan tertentu

Umumnya semua indeks harga saham gabungan (composite) menggunakan metode rata-rata tertimbang (weighted arithmetic mean) termasuk di Bursa Efek Indonesia. Seperti halnya penghitungan indeks di bursa lainnya, penghitungan indeks di BEI menggunakan rata-rata tertimbang dari nilai pasar (market value weighted average index).

Rumus dasar penghitungan indeks adalah:

$$
\text { Nilai Dasar Baru }=\frac{\text { Nilai Pasar Lama }+ \text { Nilai Pasar Baru }}{\text { Nilai Pasar Lama }} \text { xilai Dasar Lama }
$$

Nilai Pasar adalah kumulatif jumlah saham hari ini dikali harga pasar hari ini atau disebut sebagai kapitalisasi pasar. Nilai dasar adalah nilai yang dihitung berdasarkan harga perdana dari masing-masing saham atau berdasarkan harga yang telah dikoreksi jika perusahaan telah melakukan kegiatan yang menyebabkan jumlah saham yang tercatat di bursa berubah. Penyesuaian dilakukan agar indeks akan benar-benar mencerminkan pergerakan harga saham.

Indeks Regional. Straits Times Indeks (STI) Straits Times Index (STI) sebagai indikator pergerakan harga saham yang mencakup harga saham dari 50 perusahaan yang tercatat di Bursa Singapura. Dalam rangka menggerakan perusahaan yang termasuk dalam sektor mayor bursa, khususnya di bidang perindustrian Singapura maka diterbitkan Straits Times Industrials Index (STII) yang terdiri dari perusahaan-perusahaan yang termasuk dalam sektor mayor di bursa.

Tambahan saham baru dimasukkan pada tanggal 5 Feb 2007 termasuk Thai Beverage, Suntec REIT, Olam, Genting International, Labroy Marine dan Capital Commercial Trust. BIL, Dairy Farm, Haw Par Corporation dan TPV Technology akan dikeluarkan dari papan perdagangan. Dengan perubahan ini, 50 saham di STI akan mempunyai $51 \%$ rata-rata perdagangan harian pada Bursa Singapura dan 64\% nilai pasar pada saham yang tercatat di Bursa Singapura.

Penghitungan STI. Pada tahun 1997, ditetapkan sebagai tahun dasar yang akan diambil sebagai average of the daily aggregate market value (AMV), kecuali indeks AllSingEquities yang rata - rata perdagangan harian dimulai tahun 1975. Daily AMV diperuntukkan perusahan yang sudah tercatat di bursa pada tanggal 3 Januari 1997 (untuk All-Sing Equities Index, daily AMV digunakan untuk perusahaan yang tercatat di bursa pada tanggal 2 Januari 1975). Perusahaan yang tercatat di bursa setelah tanggal tersebut tidak dihitung dengan penghitungan dasar pembukaan.

$$
\text { Indeks }=\frac{\text { Jumlah Saham Tercatat } x \text { Harga terakhir }}{\text { Jumlah Saham Perdana } x \text { Harga Perdana }} \times 100
$$

Kuala Lumpur Composite Index (KLCI). Kuala Lumpur Composite Index (KLCI) adalah indeks yang terdiri dari 100 perusahaan yang terdaftar di papan atas bursa Malaysia sebagai indeks pengukur pergerakan harga saham yang memiliki nilai kapitalisasi pasar besar di Bursa. Bulan Juni 2006, indeks diterbitkan secara bersama oleh Bursa Malaysia dan Financial Times Stock Exchange (FTSE). 
Penghitungan KLCI. KLCI dihitung dengan metode "Market Capiltalization - Weighted" indeks terdiri dari 100 saham pilihan. Dengan tahun dasar 1977.

$$
\text { Indeks }=\frac{\text { Jumlah Saham Tercatat } \mathrm{x} \text { Harga terakhir }}{\text { Jumlah Saham Perdana } \mathrm{x} \text { Harga Perdana }} x 100
$$

Stock Exchange of Thailand Index (SETI). SETI adalah indeks yang dapat dihitung berdasarkan seluruh saham yang terdapat pada Papan Utama Bursa (termasuk unit trusts of property funds ) Thailand, Kecuali saham yang telah di suspend lebih dari 1 tahun .

Penghitungan SETI. Indeks SETI mempunyai tahun dasar yang dihitung sejak 30 April 1975, yang mana pada saat berdiri indeks SETI telah ditetapkan sebesar 100 . SETI juga mempunyai indeks kelompok industri dan sektoral. Yang mana keduanya dihitung berdasar harga saham yang mempunyai fundamental yang sama yang mempunyai kriteria sebagai kelompok industri dan sektor.

$$
\text { Indeks }=\frac{\text { Jumlah Saham Tercatat } x \text { Harga terakhir }}{\text { Jumlah Saham Perdana } x \text { Harga Perdana }} x 100
$$

Nikkei. Nikkei adalah indeks harga saham untuk Bursa Efek Tokyo (Tokyo Stock Exchange/TSE). Nihon Kaizui Simbun adalah lembaga yang diberi wewenang untuk melaksanakan Nikkei Stock Average yang berfungsi sebagai indikator pergerakan rata-rata harga saham.

Sejak tahun 1971, Nikkei adalah harganya diperhitungankan berdasarkan mata uang Yen, Nikkei mulai dihitung sejak 7 September 1950, secara otomatis akan dihitung ulang pada 16 Mei 1949. Nikkei adalah terdiri dari 225 saham-saham yang mempunyai kapitalisasi pasar yang besar dan terdaftar di papan atas bursa Tokyo sebagai indeks pengukur pergerakan harga saham.

Pergerakan Nikkei berkorelasi kuat dengan pergerakan indeks saham NASDAQ. Nikkei 225 Futures, telah diperkenalkan pada the Osaka Securities Exchange (OSE), Chicago Mercantile Exchange (CME), Singapore Exchange (SGX), sekarang dikenal secara internasional sebagai indeks future Penghitungan Nikkei

Penghitungan Nikkei. Metode penghitungan indeks Nikkei menggunakan Weighted Averaged Method seperti halnya penghitungan indeks DOWJONES.

$$
\text { Indeks }=\frac{\text { Jumlah Saham Tercatat } \mathrm{x} \text { Harga terakhir }}{\text { Jumlah Saham Perdana } \mathrm{x} \text { Harga Perdana }} x 100
$$

Hang Seng Index (H S I). Hang Seng Index (H S I), sebagai barometer terkemuka dari harga saham yang mempunyai kapitalisasi yang besar di bursa Hongkong. HSI adalah salah satu indeks terkenal di kawasan Asia dan telah digunakan secara meluas oleh para manager keuangan sebagai performance benchmark mereka. HSI juga digunakan untuk mencatat dan mengawasi pergerakan harga saham dari perusahaan-perusahaan yang tercatat di Bursa Efek Hongkong. Terdapat 33 perusahaan pilihan yang terdapat di indeks Hang Seng semuanya adalah perusahaan terkemuka dan para investor institusi. 
Sejak diperkenalkannya indeks Hang Seng pada tangggal 24 November 1979, perkembangan dari indeks Hang Seng dengan saham-saham terpilihnya telah merefleksikan kepentingan dari berbagai sektor industri. Saham pilihan dengan kapitalisasi pasar yang tinggi akan mempunyai dampak yang lebih besar dibandingkan dengan saham yang mempunyai kapitalisasi pasar. Saham account ini di atas $70 \%$ dari seluruh kapitalisasi pasar dari semua saham yang terdapat di SEHK (Stock Exchange Hongkong). Kemudian perusahaan yang masuk dalam pilihan Hangseng sebanyak 38 perusahaan, yang menjadikan persentase kapitalisasi Bursa Efek Hongkong menjadi $65 \%$.

Penghitungan Hangseng. Indeks Hang Seng, yang dihitung dengan metode Market Capiltalization - Weighted index terdiri dari 33 saham pilihan. Pengaruh setiap saham pada indeks, berpengaruh langsung pada nilai pasarnya.

$$
\text { Harga indeks }==\frac{\sum[P(t) x I S x F A F x C F]}{\sum[P(t-1) x I S x F A F x C F]} \quad \mathrm{x} \text { harga penutupan }
$$

Dimana: $\mathrm{P}(\mathrm{t})=$ harga saham pada hari $\mathrm{t} ; \mathrm{P}(\mathrm{t}-1)=$ harga penutupan pada hari $(\mathrm{t}-1)$; IS (Issued Shares) $=$ penerbitan saham; FAF(Freefloat-adjusted Factor), yang nilainya antara 0 dan 1, disesuaikan setiap enam bulan; CF (Cap Factor), yang nilainya antara 0 dan 1, disesuaikan setiap enam bulan

Indeks yang ada di BEI. Di Bursa Efek Indonesia macam-macam indeks yaitu: Pertama. Indeks Harga Saham Gabungan (IHSG). Pada tanggal 1 april 1983 Indeks Harga Saham Gabungan (IHSG) di perkenalkan untuk pertama kalinya sebagai indikator pergerakan harga saham di BEI. Indeks ini mencakup pergerakan harga seluruh saham biasa dan preferen yang tercatat di Bursa Efek Indonesia (BEI). Hari dasar untuk penghitungan IHSG adalah tanggal 10 Agustus 1982. Pada tanggal tersebut, indeks ditetapkan dengan nilai dasar 100 dan saham tercatat pada saat itu berjumlah 13 saham Indeks Harga Saham Gabungan atau IHSG (composite share price index), menggunakan semua saham yang tercatat sebagai komponen penghitungan indeks.

Cara melihat Indeks Harga Saham Gabungan yaitu bila angka positif yang menyertai perubahan Indeks Harga Saham menunjukkan adanya kenaikan dari Indeks Harga Saham sebelumnya. Angka negatif menunjukkan indeks harga saham turun dibanding indeks harga saham sebelumnya. Jika indeks harga saham tidak berubah menunjukkan bahwa kondisi stabil, sehingga ukurannya betul-betul menjadi indikator yang representatif. Rumus Indeks Harga Saham Gabungan:

$$
\mathrm{IHSG}=\frac{\sum \mathrm{H}_{1} \mathrm{x} 100 \%}{\sum \mathrm{H}_{0}}
$$

Keterangan : H1 adalah seluruh jumlah harga saham yang terakhir.

$\mathrm{H} 0$ adalah jumlah harga saham pada waktu dasar.

Penghitungan IHSG dilakukan setiap hari, yaitu setelah penutupan perdagangan setiap harinya. Dalam waktu dekat, diharapkan penghitungan IHSG dapat dilakukan beberapa kali atau bahkan dalam beberapa menit, hal ini dapat dilakukan setelah sistem perdagangan otomasi diimplementasikan dengan baik. 
Kedua. Indeks LQ 45. Indeks LQ 45, menggunakan 45 saham yang terpilih berdasarkan likuiditas perdagangan saham dan disesuaikan setiap enam bulan (setiap awal bulan Februari dan Agustus). Dengan demikian saham yang terdapat dalam indeks tersebut akan selalu berubah. Setiap 3 bulan, di review pergerakan rangking saham yang masuk dalam penghitungan Indeks LQ 45. Penggantian saham akan dilakukan setiap 6 bulan sekali yaitu pada setiap awal bulan Februari dan Agustus. Bila ada satu saham yang tidak memenuhi kriteria tersebut akan dikeluarkan dari penghitungan indeks dan digantikan dengan saham yang memenuhi kriteria. Saham-saham yang masuk dalam kriteria rangking 1-35 dikalkulasikan dengan cepat dalam penghitungan indeks. Sedangkan saham yang masuk pada rangking 36-45 tidak perlu dimasukkan dalam penghitungan indeks

LQ 45 dihitung mundur hingga tanggal 13 Juli 1994 sebagai hari dasar, dengan nilai dasar 100. Untuk seleksi awal digunakan data pasar dari bulan Juli 1993 sampai Juni 1994. Hasilnya akan masuk ke 45 saham tersebut, meliputi $72 \%$ total kapitalisasi pasar dan $72,5 \%$ nilai transaksi di pasar reguler.

Ketiga. Indeks sektoral. Indeks harga saham sektoral, menggunakan semua saham yang termasuk dalam masing-masing sektor dan merupakan bagian dari IHSG. Semua perusahaan yang tercatat di BEJ di klasifikasikan ke dalam 9 sektor yang didasarkan pada klasifikasi industri yang ditetapkan oleh BEI yang di sebut JASICA (Jakarta Stock Exchange Industrial Classification). Keempat. Jakarta Islamic Indeks (JII). JII terdiri dari 30 saham yang sesuai dengan syariah Islam. Dewan pengawas syariah PT DIM terlibat dalam menetapkan kriteria saham-saham yang masuk dalam JII. Indeks Syariah atau JII (Jakarta Islamic Index). JII merupakan indeks terakhir yang dikembangkan oleh BEI bekerjasama dengan Danareksa Investment. Indeks ini merupakan indeks yang mengakomodasi syariat investasi Islam atau indeks yang berdasarkan syariah Islam. JII dihitung mundur hingga tanggal 1 Januari 1995 sebagai hari dasar dengan nilai dasar 100.

Kelima. Indeks Papan Utama (Main Board Index/MBX) dan Indeks Papan Pengembang (Development Board Index/DBX). Kedua indeks diluncurkan pada tanggal 8 April 2002. Indeks Papan Utama untuk perusahaan besar dengan track record yang baik dan Indeks Papan Pengembang untuk mengakomodasi perusahaan-perusahaan yang belum bias memenuhi persyaratan pada Papan Utama, tetapi masuk pada kategori perusahaan berprospek. Hari dasar untuk perhitungan kedua indeks yaitu tanggal 28 Desember 2001 dengan Nilai Dasar 100.

Keenam. Indeks Harga Saham Individual (IHSI). Indeks harga masing-masing saham terhadap harga dasarnya. yang mencerminkan perkembangan harga suatu saham. BEI memberi angka dasar IHSI 100 ketika saham diluncurkan pada pasar perdana dan berubah sesuai dengan perubahan pasar.

Bursa Saham Singapura (SGX/ Singapore Exchange Limited). Singapore Exchange Limited (SGX) adalah bursa pertama di Asia-Pasifik yang terdiri dari sekuritas dan derivatif. SGX telah diresmikan pada tanggal 1 Desember 1999, sejalan dengan penggabungan merger antara dua perusahaan dan yang dikenal sebagai institusi keuangan yaitu Stock Exchange of Singapore (SES) dan Singapore International Monetary Exchange (SIMEX).

Pada 23 November 2000, SGX menjadi bursa pertama di Asia-Pasifik yang dapat melakukan penawaran baik secara publik maupun private. Yang terbit dalam bursa saham mereka, saham SGX adalah sebuah komponen yang merupakan cabang dari MSCI Singapore Free Index dan Straits Times Index (STI). SGX menjadi bursa dunia yang 
pertama yang menarik investor dunia dan menawarkan offshore risk management centre Asia untuk internasional derivatif.

Penghitungan berlaku untuk semua saham yang tercatat pada papan utama Bursa Singapura dan perusahaan perdagangan dengan nilai tukar pada sektor menyangkut indeks. Dimasa yang akan datang, hanya saham tertentu saja yang mempergunakan penghitungan aggregate market value. Sedangkan untuk saham yang baru diterbitkan akan diberikan waktu selama satu bulan untuk dapat masuk dalam indeks utama. Saham lokal maupun luar negeri akan mempunyai market capitalisation weighted berdasar respective foreign limits. Metode penghitungan untuk ketiga indeks sama seperti indeks AllSingEquities Dengan tahun dasar 2 Januari 1996.

Indeks-Indeks yang ada di Bursa Efek Singapura: (1) Straits Times. Sama seperti IHSG pada Indonesia, Indeks ini mencakup pergerakan harga seluruh saham biasa dan preferen yang tercatat di Bursa Efek Singapura. Penghitungan Straits Times Indeks dilakukan setiap hari, yaitu setelah penutupan perdagangan setiap harinya. Dalam waktu dekat, diharapkan penghitungan STI dapat dilakukan beberapa kali atau bahkan dalam beberapa menit, hal ini dapat dilakukan setelah sistem perdagangan otomasi diimplementasikan dengan baik; (2) All SingEquities. Dalam BEI dikenal dengan nama indeks harga saham sektoral, menggunakan semua saham yang termasuk dalam masingmasing sektor dan merupakan bagian dari Straits Times. Semua perusahaan yang tercatat di bursa Singapura diklasifikasikan dalam beberapa sektor yang didasarkan pada klasifikasi industri yang ditetapkan oleh Bursa Singapura Kesembilan Indeksnya yaitu: perdagangan, keuangan, pengelolahan/ manufaktur, aneka industri, properti, real estate, jasa,transportasi, investasi dan komunikasi.; (3) BT-Singapore Regional Index (BT-SRI). BT-SRI mempunyai dua fungsi yaitu sebagai indikator ekonomi untuk daerah asia dan sebagai indeks yang dapat digunakan sebagai patokan dalam SES listed stocks dengan eksposure substansial dari berbagai daerah. BT-SRI mempunyai 38 saham baik perusahaan dalam negeri maupun luar negeri yang meliputi sektor industri yang mempunyai proporsi pendapatan dan laba berdasar aktivitas daerah Asia. Yang termasuk dalam sektor industri yaitu perkapalan, makanan dan minuman, keuangan, perdagangan, telekomunikasi, pembangunan, hotel dan transportasi, yang memberikan keuntungan untuk pasar modal Singapura .

Bursa Saham Malaysia (KLSE/Kuala Lumpur Srock Exchange). Bursa Malaysia, dahulunya dikenali sebagai Bursa Saham Kuala Lumpur (KLSE/ Kuala Lumpur Stock Exchange) yang telah didirikan pada tahun 1930 dan perkumpulan broker-broker saham Singapura telah didirikan secara resmi sebagai sekuritas-sekuritas di Tanah Melayu. Pada tahun 1937, Bursa masih terdaftar sebagai perkumpulan broker-broker saham Tanah Melayu tapi masih tidak menawarkan saham-saham Malaysia. Pada tahun 1960 telah didirikan Bursa saham resmi yang pertama yaitu Bursa Saham Malaysia, yang mempunyai dua kamar perdagangan yaitu di Singapura dan Kuala Lumpur. , Bursa Saham Malaysia dan Singapura (SEMS) di bubarkan pada tahun 1965. Dengan terhentinya kerjasama antara Negara Singapura dan Malaysia pada 1973, SEMS berpecah menjadi dua, yaitu Bursa Saham Kuala Lumpur Berhad (KLSEB) dan Bursa Saham Singapura. Didirikan sebuah organisasi baru oleh Malaysia, yaitu Bursa Saham Kuala Lumpur (KLSE) yang mengambil alih operasi KLSEB pada tahun 1976. Yang merupakan langkah 
awal dari pemisahan, dengan KLSE menjadi sebuah perusahaan terbuka pada tanggal 5 Januari 2005.

Dengan pemisahaan kedua bursa itu, KLSE memberi kuasa dan memindahkan sepenuhnya bursa sahamnya kepada anak perusahaan miliknya yaitu Bursa Malaysia Securities Berhad, yang mana KLSE yang telah terpisah menjadi perusahaan induk bursa yang di kenal sebagai Bursa Malaysia, yang beroperasi mulai tanggal 20 April 2004. Bursa Malaysia kini merupakan salah satu bursa terbesar di ASEAN, dengan 953 perusahaan (pada tanggal 19 November 2004) tercatat di papan utama, papan kedua atau pasar MESDAQ. Perusahaan-perusahaan ini yang mencerminkan berbagai ruang lingkup ekonomi Malaysia yang dikategorikan kepada 14 sektor berlainan untuk peladangan, perdagangan, hingga kepada teknologi, infrastruktur dan keuangan, dan lain-lain. Pada tahun ini, terdapat 34 perusahaan broker saham yang dikenal sebagai Organisasiorganisasi peserta yang menawarkan perdagangan-perdagangan mengenai sekuritas yang tercatat di Bursa Malaysia Sekuritias. Terdapat enam perusahaan broker saham yang telah diakui oleh dunia. Broker-broker ini berupaya untuk menawarkan satu lingkup perdagangan-peradagangan pasar modal, yaitu keuangan perusahaan, perdagangan sekuritas hutang dan urusan niaga saham.

Indeks-indeks yang ada di Bursa Efek Malaysia. Pertama. Kuala Lumpur Composite Index (KLCI). Sama seperti halnya IHSG pada BEI, sebagai indikator pergerakan harga saham di BEI. Indeks ini mencakup pergerakan harga seluruh saham biasa dan preferen yang tercatat di Bursa Efek Malaysia . Penghitungan Indeks dilakukan setiap hari, yaitu setelah penutupan perdagangan setiap harinya. Dalam waktu dekat, diharapkan penghitungan Indeks gabungan Kuala Lumpur (KLCI) dapat dilakukan beberapa kali atau bahkan dalam beberapa menit, hal ini dapat dilakukan setelah system perdagangan otomasi diimplementasikan dengan baik. Kedua. Indeks Sektoral. Dalam BEI dikenal dengan nama Indeks harga saham sektoral, menggunakan semua saham yang termasuk dalam masing-masing sektor dan merupakan bagian dari KLCI. Semua perusahaan yang tercatat di KLSE di klasifikasikan ke dalam 9 sektor yang didasarkan pada klasifikasi industri yang ditetapkan oleh Bursa Malaysia Kesembilan Indeksnya yaitu: konsumen, industri barang, pembangunan, perdagangan/jasa, teknologi, keuangan, properti, perkebunan, pertambangan. Ketiga. Syariah. Indeks Ini sama seperti pada Jakarta Islamic Index pada BEI. Indeks ini merupakan indeks yang mengakomodasi syariat investasi Islam atau Indeks yang berdasarkan syariah Islam. Investasi yang kegiatan usahanya tidak bertentangan dengan Syariah Islam; Keempat. Second Board. Sama seperti papan pengembang pada Bursa Efek Indonesia. Di implementasikan untuk mendorong bursa Malaysia dan juga untuk memulihkan kepercayaan publik kepada bursa melalui penyusunan. Pengelolahan Perusahaan yang baik (Good Corporate Governance). Dalam rangka menyediakan indikator untuk mengawasi saham-saham yang masuk dalam kategori setiap papan perdagangan. Kelima. Financial Times Stock Exchange (FTSE) Bursa Malaysia Index Series.

FTSE Bursa Malaysia Index Series untuk mengukur atas pergerakan pasar modal di Malaysia. Semua perusahaan yang tercatat dalam papan utama bursa Malaysia dapat dimasukan dalam subyek untuk pertemuan standar internasional FTSE atas free float, liquidity dan investability. Indeks ini melindungi semua saham di pasar modal dan cocok untuk sebagai investasi produk seperti derivatif dan index tracking funds. Yang termasuk 
dalam Financial Times Stock Exchange (FTSE) Bursa Malaysia Indeks series yaitu: (1) FTSE Bursa Malaysia (FBM) 100. Indeks ini meliputi 100 perusahaan terbesar pada FTSE Bursa Malaysia (FBM) EMAS indeks berdasarkan kapitalisasi pasar; (2) FTSE Bursa Malaysia (FBM) 30. Indeks ini meliputi 30 perusahaan terbesar pada FTSE Bursa Malaysia (FBM) EMAS indeks berdasarkan kapitalisasi pasar; (3) FTSE Bursa Malaysia (FBM) 70. Indeks ini meliputi 70 perusahaan terbesar pada FTSE Bursa Malaysia (FBM) EMAS indeks berdasarkan kapitalisasi pasar; (4) FTSE Bursa Malaysia (FBM) EMAS. Indeks FTSE Bursa Malaysia EMAS Shariah menjadi indeks FBM EMAS yang berdasarkan Syariah yang ditetapkan dalam Securities Commission's SAC screening methodology dan FINANCIAL TIMES STOCK EXCHANGE (FTSE)'s screens of free float, liquidity dan investability; (5) FTSE Bursa Malaysia (FBM) HIJRAH. Indeks FTSE Bursa Malaysia Hijrah Shariah adalah sebuah indeks yang terdiri datri 30 perusahaan terbesar yang termasuk dalam indeks FBM EMAS yang sudah melalui 3 proses melalui : (a) FTSE's global standards of free float, liquidity dan investability; (b) Yasaar's international Shariah screening methodology; (c) Malaysian Securities Commission's Shariah Advisory Council (SAC) screening Methodology

\section{METODE}

Metode Analisis Data. Metode analisis yang digunakan untuk menganalisis pergerakan menggunakan metode analisa top-down dan analisia statistik deskriptif. Dalam penelitian ini penulis mengolah data ke dalam bentuk gambar grafik dan tabulasi sehingga mudah dipahami dan di mengerti.

Menurut situs investorwords, analisa top-down yaitu analisa yang di lihat dari kondisi global kemudian kondisi nasional (makro/mikro, moneter/fiskal, politik dll) sampai dengan kondisi sektor industri, dan ke kondisi khusus dari perusahaan yang diwakili oleh harga sahamnya. Penulis menggunakan ukuran pemusatan dengan menggunakan rata-rata (average), yaitu membandingkan antara dua kelompok atau lebih. Dengan rumus:

$$
\bar{X}=\frac{1}{n} \sum_{i=1}^{n} X i
$$

Dimana: $\mathrm{n}=$ banyaknya sampel yang dihitung; $\bar{X}=$ rata-rata sampel; $X i=$ penjumlahan seluruh sampel

Untuk ukuran variasi atau dispersi, penulis menggunakan simpangan baku (standard deviation). Simpangan baku merupakan salah satu ukuran dispersi yang paling banyak digunakan sebab mempunyai sifat-sifat matematis (mathematical property) yang sangat penting dan berguna sekali ubntuk pembahasan teori dan analisis. Dengan rumus:

$\sigma=\sqrt{\frac{\sum(X i-X)^{2}}{n-1}}$

Untuk mengetahui besarnya rentang data yang diteliti, penulis menggunakan nilai maksimum dan nilai minimum dengan menggunakan bantuan Microsoft Excel.

Nilai maksimum $=\max ($ range data $)$

Nilai minimum $=\min ($ range data $)$ 
Kemudian penulis mengukur seberapa kuat hubungan antar indeks secara individu dengan menggunakan rumus lorelasi linear sederhana dengan rumus :

$$
r_{x y}=\frac{n \Sigma X i Y i-\Sigma X i \Sigma Y i}{\sqrt{n \Sigma X i^{2}-\left(\Sigma X i^{2}\right)} \sqrt{n \Sigma Y i^{2}-(\Sigma Y i)^{2}}}
$$

Untuk mengukur korelasi antara variabel dependen (IHSG) dan dua variabel independen (STI dan KLCI) secara bersama-sama yaitudengan menggunakan koefisien korelasi linear berganda (KKLB) dengan rumus:

$$
R y x_{1} x_{2}=\sqrt{\frac{r_{y x 1}^{2}+r_{y x 2}^{2}-2 r^{2}{ }_{y x 1} \cdot r^{2}{ }_{y x 2} \cdot r_{x 1 x 2}^{2}}{1-r_{x i x 2}^{2}}}
$$

Dimana: Ry. $\mathrm{x}_{1} \mathrm{X}_{2}=$ Korelasi antara variabel $\mathrm{X}_{1}$ dengan $\mathrm{X}_{2}$ secara bersama-sama dengan variabel $\mathrm{Y} ; \mathrm{r} \mathrm{yx}_{1}=$ Korelasi antara $\mathrm{X}_{1}$ dengan $\mathrm{Y}$; $\mathrm{r}_{\mathrm{yx}}=$ Korelasi antara $\mathrm{X}_{2}$ dengan $\mathrm{Y} ; \mathrm{r}$ $\mathrm{x}_{1} \mathrm{X}_{2}=$ Korelasi antara $\mathrm{X}_{1}$ dengan $\mathrm{X}_{2}$

Untuk mengetahui seberapa besar tingkat kemiringan (slope) yang mencerminkan kontribusi dari $\mathrm{X}$ terhadap naik turunnya nilai $\mathrm{Y}$ maka dihitung dengan koefisien penentuan (KP) atau coefficient of determination (COD). Dengan rumus:

$\mathrm{KP}=\mathrm{r}^{2}$

$$
\mathrm{COD}=\frac{\% \text { varians of } \mathrm{Y}}{\% \text { varian of } \mathrm{X}}
$$

Setelah mengukur korelasi maka didapat persamaan fungsi linear berganda yang menggambarkan korelasi antara variabel $\mathrm{X}_{1}, \mathrm{X}_{2}$ dan $\mathrm{Y}$.

$$
Y^{\prime}=b_{0}+b_{1} x_{1}+b_{2} x_{2}
$$

Dimana : $\mathrm{b}_{0}=$ Nilai $\mathrm{Y}^{1}$, kalau $\mathrm{X}_{1}=\mathrm{X}_{2}=0 ; \mathrm{b}_{1}=$ Besarnya kenaikan (penurunan) $\mathrm{Y}$ dalam satuan, kalau $\mathrm{X}_{1}$ naik(turun) satu satuan, sedangkan $\mathrm{X}_{2}$ konstan; $\mathrm{b}_{2}=$ Besarnya kenaikan

\begin{tabular}{|c|c|c|c|c|c|}
\hline No. & Variabel & Definisi & Indikator & Simbol & $\begin{array}{l}\text { Skala } \\
\text { Data }\end{array}$ \\
\hline 1 & STI & $\begin{array}{l}\text { Variabel Independen, nilai gabungan } \\
\text { dari saham-saham SGX }\end{array}$ & Poin & $\mathrm{X}_{1}$ & Rasio \\
\hline 2 & KLCI & $\begin{array}{l}\text { Variabel Independen, nilai gabungan } \\
\text { dari saham-saham KLSE }\end{array}$ & Poin & $\mathrm{X}_{2}$ & Rasio \\
\hline 3 & IHSG & $\begin{array}{l}\text { Variabel dependen, nilai gabungan dari } \\
\text { saham-saham BEI }\end{array}$ & Poin & $\mathrm{Y}$ & Rasio \\
\hline 4 & $\begin{array}{l}\text { Koefisien } \\
\text { Korelasi }\end{array}$ & $\begin{array}{l}\text { Menggambarkan seberapa kuat } \\
\text { hubungan antar variable X dan Y }\end{array}$ & Persentase & $\rho($ rho $)$ & Rasio \\
\hline
\end{tabular}
(penurunan) $\mathrm{Y}$ dalam satuan, kalau $\mathrm{X}_{2}$ naik(turun) satu satuan, sedangkan $\mathrm{X}_{1}$ konstan

Variabel yang diteliti dikelompokkan sebagai berikut :

Tabel 1. Operasionalisasi Variabel 
Ekadjaja: Pengaruh Indeks Bursa Regional Terhadap Indeks Harga Saham Gabungan...

\begin{tabular}{cccccc}
\hline No. & Variabel & \multicolumn{1}{c}{ Definisi } & Indikator & Simbol & $\begin{array}{c}\text { Skala } \\
\text { Data }\end{array}$ \\
\hline 5 & Max & $\begin{array}{l}\text { Nilai terbesar selama periode } \\
\text { penelitian } \\
\text { Nilai terkecil selama periode } \\
\text { penelitian }\end{array}$ & Poin & X max & Rasio \\
6 & Min & Poin & X min & Rasio \\
7 & $\begin{array}{l}\text { Standar } \\
\text { Deviasi }\end{array}$ & $\begin{array}{l}\text { Mengukur perbedaan antara sebuah } \\
\text { level harga(high, low, close } \text { atau } \text { open }) \\
\text { dengan nilai rata-ratanya }\end{array}$ & Poin & o & Rasio \\
\hline
\end{tabular}

Sumber: penulis

\section{PEMBAHASAN}

Analisis Pergerakan IHSG BEI. Dalam melakukan pengolahan data, penulis harus menentukan sampel yang digunakan dalam penelitian ini. Sampel yang diambil adalah Indeks Harga Saham Gabungan BEI. Penulis mengambil sampel harga indeks berdasarkan kurun waktu lima tahun 2008-2012. Rata-rata (Average) dapat diperoleh dengan membagi rata-rata indeks dari 2008 - 2012:

$$
\bar{X}=\frac{1}{n} \sum_{i=1}^{n} X i \text { dan diperoleh } \bar{X}=1398.131
$$

Jadi rata-rata pergerakan indeks IHSG dari 2008-2012 sebesar 1398.131 poin. Batas atas (Upper Bound) adalah batas atas dari sebuah grafik pergerakan IHSG yang diperoleh dari nilai average, standar deviasi dan $Z$ point.

Batas atas = average $+($ standar deviasi $\mathrm{x} Z$ point $)$, diperoleh batas atas $=1958.23$

Jadi pergerakan batas atas indeks IHSG dari periode 2008 hingga 2012 sebesar 1959.884 poin dengan $\mathrm{Zp}(\mathrm{p}=0.95)=\mathrm{Z}_{0.95}=1.64$. Berarti bila indeks mengalami kenaikan hingga mencapai batas atas kemungkinan indeks akan terus menaik atau indeks akan memantul kebawah (reversal down).

Batas bawah (Lower Bound) adalah batas bawah dari grafik pergerakan IHSG yang diperoleh dari nilai average, standar deviasi dan $Z$ point.

Batas bawah = average $-($ standar deviasi $\mathrm{x} Z$ point $)$, diperoleh batas bawah $=838.04$

Jadi batas bawah dari pergerakan indeks IHSG dari periode 2008 hingga 2012 sebesar 836.3784 poin dengan $\mathrm{Zp}(\mathrm{p}=0.95)=\mathrm{Z}_{0.95}=1.64$. Berarti bila indeks telah menyentuh batas bawah, kemungkinan akan mengalami penurunan atau mengalami memantul ke atas (reversal up).

Analisis Pergerakan Straits Times Index (STI).Rata-rata (Average) dapat diperoleh dengan membagi rata-rata indeks 2008-2012 :

$$
\bar{X}=\frac{1}{n} \sum_{i=1}^{n} X i, \text { dan diperoleh } \bar{X}=2579.37
$$

Jadi rata-rata pergerakan indeks STI dari 2008 hingga 2012 sebesar 2580.536 poin. Batas atas (Upper Bound) adalah batas atas dari sebuah grafik pergerakan STI yang diperoleh dari nilai average, standar deviasi dan $Z$ point. Batas atas $=$ average $+($ standar deviasi $x Z$ poin $)=3289.87$. Jadi pergerakan batas atas indeks STI dari 2008 hingga 
2012 sebesar 3291.972 poin dengan $\mathrm{Zp}(\mathrm{p}=0.95)=\mathrm{Z}_{0.95}=1.64$. Berarti bila indeks mengalami kenaikan hingga mencapai batas atas kemungkinan indeks akan terus menaik atau indeks akan memantul kebawah (reversal down). Batas bawah (Lower Bound) adalah batas bawah grafik pergerakan STI yang diperoleh diperoleh dari nilai average, standar deviasi dan $Z$ point Batas atas $=$ average $-($ standar deviasi $\times Z$ point $)=$ 1871.2

Jadi batas bawah dari pergerakan indeks STI dari 2008 hingga 2012 sebesar 1869.101 poin dengan $\mathrm{Zp}(\mathrm{p}=0.95)=\mathrm{Z}_{0.95}=1.64$. Berarti bila indeks telah menyentuh batas bawah, kemungkinan akan mengalami penurunan atau mengalami memantul ke atas (reversal up).

Analisis Pergerakan Kuala Lumpur Composite Index (KLCI). Rata-rata (Average) dapat diperoleh dengan membagi rata-rata indeks dari 2008-2012:

$$
\bar{X}=\frac{1}{n} \sum_{i=1}^{n} X i \text { dan diperoleh } \bar{X}=1001.75
$$

Batas atas (Upper Bound) adalah batas atas dari sebuah grafik pergerakan KLCI yang diperoleh dari nilai average, standar deviasi dan $Z$ point . Batas atas $=$ average $+($ standar deviasi $\mathrm{x} Z$ point $)=1250.07$

Jadi pergerakan batas atas indeks KLCI dari 2008-2012 sebesar 1250.804 poin dengan Zp $(\mathrm{p}=0.95)=\mathrm{Z}_{0.95}=1.64$. Berarti bila indeks mengalami kenaikan hingga mencapai batas atas kemungkinan indeks akan terus menaik atau indeks akan memantul kebawah (reversal down).

Batas bawah (Lower Bound) adalah batas bawah dari grafik pergerakan KLCI yang diperoleh dari nilai average, standar deviasi dan $Z$ point.

Batas atas $=$ average $-($ standar deviasi $\times \mathrm{Z}$ point $)=753.42$

Jadi batas bawah dari pergerakan indeks KLCI dari 2008 hingga 2012 sebesar 752.6873 poin dengan $\mathrm{Zp}(\mathrm{p}=0.95)=\mathrm{Z}_{0.95}=1.64$. Berarti bila indeks telah menyentuh batas bawah, kemungkinan akan mengalami penurunan atau mengalami memantul ke atas (reversal up).

Analisis perbandingan IHSG dengan Bursa Regional. Dalam penelitiannya ini, Sampel yang diambil oleh penulis adalah indeks- indeks regional, yang mana penulis mengambil dua indeks yang di jadikan patokan dalam membandingkan pergerakan Indeks Harga Saham Gabungan BEI. Penulis mengambil sampel indeks berdasarkan periode 20082012. Penulis mengambil indeks yang pergerakannya mengapit harga indeks BEI yaitu indeks Singapura (STI) dan Kuala Lumpur (KLCI). Yang mana sampel yang diambil untuk harga indeks regional berdasarkan periode 2008-2012.

Tabel 2. Perbandingan IHSG, STI dan KLCI

\begin{tabular}{cccc}
\hline & IHSG & STI & KLCI \\
\hline Average & 1398.13 & 2580.54 & 1001.75 \\
max & 2139.28 & 3548.2 & 1354.38 \\
min & 1029.61 & 2096.32 & 860.73 \\
STDEV & 341.52 & 432.52 & 151.42 \\
Trend & 34.836 & 45.186 & 14.356 \\
\hline
\end{tabular}


Berdasarkan hasil analisis penghitungan yang telah dilakukan selama periode 2008-2012, maka diperoleh hasil bahwa: (1) IHSG tertinggi mencapai level 2139.28 poin, terendah pada level 1029.61 poin dan pergerakan rata-rata dengan level 1398.13 poin dengan tingkat fluktuasi sebesar 341.52 sedangkan untuk Trend IHSG sebesar 34.836; (2) STI tertinggi mencapai level 3548.20 poin, terendah sampai dengan level 2096.32 poin, pergerakan rata-rata 2580.54 poin dengan tingkat fluktuasi sebesar 432.52 sedangkan untuk Trend STI sebesar 45.186; (3) KLCI tertinggi mencapai level 1354.38 poin, terendah sampai dengan level 860.73 poin, pergerakan rata-rata 1001.75 poin dengan tingkat fluktuasi sebesar 151.42 sedangkan untuk Trend KLCI sebesar 14.356; (4) Nilai Average tertinggi bila dibandingkan dengan ketiga indeks pertama ada pada STI, urutan kedua ada pada IHSG dengan terakhir ada pada KLCI; (5)Tingkat fluktuasi yang tertinggi ada pada STI kemudian yang kedua ada pada IHSG dan terakhir ada pada KLCI; (6) Trend tertinggi ada pada indeks STI kemudian IHSG dan terakhir KLCI

Analisis Korelasi antara IHSG dengan STI dan KLCI. Analisis Korelasi Linear Sederhana. Penulis melakukan analisis korelasi antar indeks secara individu dengan datadata pada sebagai berikut:

Korelasi antara IHSG dengan STI :

$$
\begin{aligned}
& r=\frac{n \Sigma X i Y i-\Sigma X i \Sigma Y i}{\sqrt{n \Sigma X i^{2}-\left(\Sigma X i^{2}\right)} \sqrt{n \Sigma Y i^{2}-(\Sigma Y i)^{2}}}=97.86 \% \\
& \mathrm{KP}=\mathrm{r}^{2}=95.76 \%
\end{aligned}
$$

Dari penghitungan di atas, korelasi antara IHSG - STI sebesar 0.978587 yang berarti pergerakan IHSG dengan STI berkorelasi kuat positif sebesar 0.978587 atau $97.86 \%$. Sedangkan nilai KP sebesar $0.957633(95.76 \%)$ yang artinya besarnya sumbangan variabel X terhadap naik turunnya Y sebesar $95.76 \%$.

Korelasi antara IHSG dengan KLCI :

$$
\begin{aligned}
& r=\frac{n \Sigma X i Y i-\Sigma X i \Sigma Y i}{\sqrt{n \Sigma X i^{2}-\left(\Sigma X i^{2}\right)} \sqrt{n \sum Y i^{2}-(\Sigma Y i)^{2}}}=93.87 \% \\
& \mathrm{KP}=\mathrm{r}^{2}=88.11 \%
\end{aligned}
$$

Dari penghitungan korelasi di atas, antara IHSG-KLCI sebesar 0.938656 yang berarti pergerakan IHSG dan STI juga berkorelasi kuat positif sebesar 0.938656 atau 93.87\%. dengan KP sebesar $0.881075(88.11 \%)$ yang artinya besarnya sumbangan variabel X terhadap naik turunnya Y sebesar $88.11 \%$.

Korelasi antara STI dengan KLCI :

$$
\begin{aligned}
& r=\frac{n \Sigma X_{i} X_{2}-\Sigma X_{i} \Sigma X_{2}}{\sqrt{n \Sigma X i^{2}-\left(\Sigma X i^{2}\right)} \sqrt{n \Sigma X_{2}^{2}-\left(\Sigma X_{2}\right)^{2}}}=97.16 \% \\
& \mathrm{KP}=\mathrm{r}^{2}=94.10 \%
\end{aligned}
$$

Dari penghitungan korelasi di atas, antara STI - KLCI sebesar 0.971649 yang berarti pergerakan STI dengan KLCI juga berkorelasi kuat positif sebesar 0.971649 atau $97.16 \%$ dengan KP sebesar $0.944102(94.41 \%)$ yang artinya besarnya sumbangan variabel X terhadap naik turunnya Y sebesar $94.41 \%$. 
Analisis Korelasi Linear Berganda. Kemudian penulis melakukan analisis antara ketiga indeks secara bersama-sama dengan mencari korelasi antar ketiga indeks yang menghasilkan penghitungan sebagai berikut:

$$
\begin{aligned}
& R y x_{1} x_{2}=\sqrt{\frac{r_{y x 1}^{2}+r^{2}{ }_{y x 2}-2 r^{2}{ }_{y x 1} \cdot r^{2}{ }_{y x 2} . r^{2}{ }_{x 1 x 2}}{1-r_{x i x 2}^{2}}}=97.99 \% \\
& \mathrm{KP}=\mathrm{R}^{2}=96.03 \%
\end{aligned}
$$

Dari penghitungan di atas, korelasi antara STI dan KLCI terhadap IHSG sebesar 0.979936 yang berarti pergerakan antara STI dan KLCI terhadap IHSG juga berkorelasi kuat positif sebesar 0.979936 atau $97.99 \%$ dengan KP sebesar 0.960274 (96.03\%) yang artinya besarnya sumbangan variabel $\mathrm{X}_{1}$ dan $\mathrm{X}_{2}$ terhadap naik turunnya $\mathrm{Y}$ sebesar $96.03 \%$ Kemudian penulis melakukan analisis korelasi berganda secara bersama-sama, dengan hasil sebagai berikut:

Tabel 3. Korelasi Linear Berganda

\begin{tabular}{|c|c|c|c|c|c|}
\hline \multicolumn{6}{|c|}{ ANOVA } \\
\hline & $d f$ & $S S$ & $M S$ & $F$ & Significance $F$ \\
\hline Regression & 2 & 3248157 & 1624079 & 326.4711 & $1.22 \mathrm{E}-19$ \\
\hline Residual & 56 & 134315.5 & 4974.648 & & \\
\hline Total & 58 & 3382473 & & & \\
\hline
\end{tabular}

\begin{tabular}{ll}
\hline \multicolumn{2}{c}{ SUMMARY OUTPUT } \\
\hline Regression Statistics \\
Multiple $R$ & 0.979944 \\
$R$ Square & 0.960291 \\
Adjusted $R$ Square & 0.957349 \\
Standard Error & 70.53118 \\
Observations & 60 \\
\hline
\end{tabular}

\begin{tabular}{|c|c|c|c|c|c|c|}
\hline & Coefficients & $\begin{array}{l}\text { Standard } \\
\text { Error }\end{array}$ & t Stat & P-value & $\begin{array}{l}\text { Lower } \\
95 \%\end{array}$ & $\begin{array}{l}\text { Upper } \\
95 \%\end{array}$ \\
\hline Intercept & -534.877 & 91.26318 & -5.86082 & $3.06 \mathrm{E}-06$ & -722.133 & -347.62 \\
\hline$X$ Variable 1 & 0.939981 & 0.128079 & 7.339094 & $6.79 \mathrm{E}-08$ & 0.677186 & 1.202777 \\
\hline$X$ Variable 2 & -0.49179 & 0.365857 & -1.34421 & 0.190066 & -1.24246 & 0.258887 \\
\hline
\end{tabular}

Jika hasil analisis diperhitungkan dalam metode penelitian, maka diperoleh :

1. IHSG : $-534.877+0.939981$ STI -0.49179 KLCI

2. Y : -534.877 , artinya bahwa bila tidak ada KLCI dan STI maka IHSG akan mengalami penurunan sebesar 534.877 poin

3. X1 : 0.939981 artinya bahwa setiap kenaikan level STI maka mengakibatkan kenaikkan pada IHSG sebesar 0.939981 poin

4. X2 : -0.49179 artinya jika ada kenaikan pada KLCI akan mengakibatkan penurunan pada IHSG sebesar 0.49179 poin

Dari penghitungan di atas didapat sebuah hasil yaitu pada baris Multiple $\mathrm{R}$ yang ada pada output regresi yaitu sebesar 0.979944 maka korelasi antara STI dan KLCI terhadap 
IHSG sebesar 0.98. Dalam hal ini korelasi antara IHSG dengan STI dan KLCI kuat $(>0.5)$ sedangkan untuk Standard Error yang dihasilkan sebesar 70.53118.

Pada kolom Adjusted $R$-square (KP) pada output regression statistics didapat angka sebesar 0.957349 . Hal ini berarti $95.73 \%$ variasi IHSG bisa dijelaskan oleh variasi pada STI dan KLCI yang dikeluarkan sedangkan sisanya $(100 \%-95.73 \%=4.27 \%)$ dijelaskan oleh variasi yang lain, misalnya keadaan politik, geografis dan lain-lain. Sedangkan untuk nilai $R$-Square 0.960291 atau $96.03 \%$ yang berarti model di atas dapat menjelaskan perilaku IHSG sebesar $96.03 \%$ (kuat). Sedangkan sisanya sebesar $3.97 \%$ tidak dapat dijelaskan oleh model ANOVA.

Analisis Uji statistik STI dan KLCI terhadap IHSG. Dalam melakukan uji statistik, penulis menganalisis STI dan KLCI terhadap IHSG dengan menggunakan uji T. Dengan menguji hipotesis antar IHSG $(\mathrm{Y})$ dengan STI $\left(\mathrm{X}_{1}\right)$ dan IHSG(Y) dengan KLCI $\left(\mathrm{X}_{2}\right)$ secara individu dengan menggunakan t- test maka $: \mathrm{H}_{0}: \rho=0$ artinya tidak ada hubungan antara variabel $\mathrm{X}$ dan $\mathrm{Y}$

$\mathrm{H}_{0}: \rho \neq 0$ artinya ada hubungan antara variabel $\mathrm{X}$ dan $\mathrm{Y}$.

Dengan rumus $t$ hitung sebagai berikut :

$$
t=\frac{r \sqrt{n-2}}{\sqrt{1-r^{2}}}
$$

Dimana: $\mathrm{r}=$ korelasi antar variabel $\mathrm{X}$ dan $\mathrm{Y} ; \mathrm{n}=$ banyaknya sampel

Dalam pengujian, penulis menggunakan uji dua pihak (two tail test) dan ANOVA, dengan tingkat kesalahan sebesar 5\% ( untuk dua sisi menjadi 0.025) dan derajat kebebasan sebesar (n-P-1 = 30-2-1=27) maka diperoleh t tabel sebesar 2.0518. Di dapat sebuah kesimpulan mengenai pergerakan STI yang mempunyai hubungan signifikan terhadap IHSG. Karena t-statistik yang diperoleh dari nilai t-stat sebesar 7.339094 lebih besar dibandingkan $\mathrm{t}$-tabel yaitu 2.0518 maka Ho ditolak. Sementara pergerakan terhadap KLCI menghasilkan kesimpulan, bahwa KLCI mempunyai hubungan yang tidak signifikan terhadap IHSG. Karena t - hitung -1.34421 lebih kecil dibandingkan dengan t-tabel sebesar 2.0518 maka $\mathrm{H}_{1}$ diterima.

Maka dapat diambil keputusan bila $\mathrm{t}$ hitung $>\mathrm{t}$ tabel maka $\mathrm{H}_{0}$ ditolak dan bila $\mathrm{t}$ hitung < t tabel maka Ha diterima. Penulis juga melakukan pengujian korelasi secara bersama-sama dengan menggunakan Uji $\mathrm{F}(F$-test $)$. Dengan menguji hipotesis antar IHSG (Y) dengan STI $\left(\mathrm{X}_{1}\right)$ dan $\mathrm{IHSG}(\mathrm{Y})$ dengan KLCI $\left(\mathrm{X}_{2}\right)$ secara individu dengan menggunakan $\mathrm{F}$ - test maka:

$\mathrm{H}_{0}: \rho_{1}=\rho_{2}=0$ artinya tidak ada hubungan antara variabel $\mathrm{X}_{1}$ dan $\mathrm{X}_{2}(\mathrm{STI}$

dan KLCI) dengan variabel Y (IHSG).

$\mathrm{H}_{1}: \rho_{1} \neq 0$ artinya ada hubungan antara variabel $\mathrm{X}_{1}$ dan $\mathrm{X}_{2}$ (STI dan KLCI) dengan variabel Y (IHSG).

Dengan rumus thitung sebagai berikut :

$$
F h=\frac{R^{2} / k}{\left(1-R^{2}\right) /(n-k-1)}
$$

Dimana : $\mathrm{R}=$ Koefisien korelasi ganda; $\mathrm{k}=$ Jumlah variabel independen; $\mathrm{n}=$ Jumlah anggota sampel 
Untuk mengurangi kesalahan maka penulis melakukan pengujian dengan hasil yang ada pada tabel 5.2. Yang di dapat suatu kesimpulan bahwa pergerakan KLCI dan STI memang berpengaruh terhadap IHSG, hal ini dapat di lihat dari nilai F-hitung sebesar 326.4711 lebih besar dibanding dengan F-tabel sebesar 3.35 dengan signifikasi 5\% $(\alpha=0,05)$ dan tingkat kebebasan / degree of fredoom (df): pada output (Numerator $=2$, sedangkan Denumerator $=27$ ) yang menghasilkan kesimpulan $\mathrm{H}_{0}$ ditolak.

Dengan menggunakan pengujian F-test yaitu dengan menguji STI dan KLCI secara bersama-sama dengan membuat hipotesis:

$\mathrm{H}_{0}: \rho_{1}=\rho_{2}=0$ artinya tidak ada hubungan antara variabel X1 dan X2 (STI dan KLCI) dengan variabel Y (IHSG).

$\mathrm{H}_{1}: \rho_{\mathrm{i}} \neq 0$ artinya ada hubungan antara variabel X1 dan X2 (STI dan KLCI) dengan variabel Y (IHSG). Maka dapat diambil keputusan bahwa $\mathrm{F}$ hitung $>\mathrm{F}$ tabel maka $\mathrm{H}_{1}$ diterima, atau bila $\mathrm{F}$ hitung $>\mathrm{F}$ tabel maka $\mathrm{H}_{0}$ ditolak.

\section{PENUTUP}

Simpulan. Pertama. Dari indeks IHSG, STI dan KLCI, tingkat fluktuasi yang paling tinggi ada pada STI sebesar 432.52, kedua IHSG sebesar 341.52, terakhir ada pada KLCI sebesar 151.42. Rata-rata ketiga indeks mengalami kenaikan yang dapat di lihat pada nilai trend dan STI memiliki nilai trend tertinggi yaitu sebesar 45.186 kemudian IHSG pada urutan kedua sebesar 34.836 dan terakhir KLCI sebesar 14.356. Kedua. Semua indeks berkorelasi positif dimana IHSG dengan STI berkorelasi lebih tinggi dibandingkan dengan KLCI. Masing-masing korelasi tersebut adalah : IHSG - STI sebesar 97.86 \%, IHSGKLCI sebesar $93.87 \%$, STI - KLCI sebesar $97.16 \%$. Ketiga. Korelasi berganda terhadap IHSG menunjukkan indeks bursa regional berkorelasi kuat positif $R y x_{1} x_{2}=97.99 \%, \mathrm{KP}=$ 96.03\% dengan menunjukkan perubahan indeks bursa regional yang dapat dijelaskan dengan model statistik.Untuk pengujian uji t, pergerakan indeks STI dengan indeks IHSG mempunyai hubungan yang signifikan terhadap IHSG karena t hitung $>\mathrm{t}$-tabel maka Ho ditolak. Sementara pergerakan terhadap KLCI menghasilkan kesimpulan, bahwa KLCI mempunyai hubungan yang tidak signifikan terhadap IHSG karena t-hitung < dibandingkan dengan t-tabel maka Ha diterima. Untuk pengujian uji $\mathrm{F}$ didapat bahwa Fhitung > F-tabel maka kesimpulannya $\mathrm{H}_{0}$ ditolak. Keempat. Korelasi antara pergerakan Indeks Indonesia (IHSG) dengan Indeks Singapura (STI) dan Kuala lumpur (KLCI) dapat dipengaruhi faktor lain yaitu pertukaran nilai tukar dolar AS terhadap Negara lain, perkembangan suku bunga The Fed, perkembangan situasi politik. Faktor-faktor lain tersebut dapat juga dijadikan sebagai bahan pertimbangan dalam melakukan investasi pada indeks harga saham gabungan

\section{DAFTAR RUJUKAN}

Amrullah,Afif.(2010) KARIATO "Indikator Andalan Pasar Global: Saham, Indeks, Komoditi dan Valas".Jakarta:Elex Media Komputindo.

Azman,Muzafar,Syah H. M, Azali. (2002) "Stock Price And Exchange Rate Interaction In Indonesia: An Empirical Inquiry". Jurnal Ekonomi dan Keuangan, Volume 1 Nomor 2002. 
Cahyono, Jaka E. (2000) 22 Strategi dan Teknik Meraih Untung di Bursa Saham. Jilid 1. Jakarta: PT Elex Media Komputindo.

Ghozali, Imam. (2001) Analisis Multivariate Dengan Program SPSS. Semarang: UNDIP.

Husnan, Suad. (2005) Dasar-Dasar Teori Portofolio dan Analisis Sekuritas. Yogyakarta: UPP AMP YKPN.

Indriantoro, Nur dan Bambang Supomo. (2000) Metodologi Penelitian Bisnis. Edisi Pertama.Yogyakarta: Penerbit BPFE.

J. Supranto. (2000) STATISTIK Teori dan Aplikasi Jilid 1\&2. Jakarta:Penerbit Erlangga.

Kwon, C. S., and Bacon, F. W. (1997) The Effect of Macroeconomic Variables on Stock Market Returns in Developing Markets. Multinational Business Review,Fall,pp.63 70.

Mansur, Moh. (2004) "Pengaruh Indeks Bursa Global Terhadap Indeks Harga Saham

Gabungan (IHSG) Pada Bursa Efek Jakarta (BEJ) Periode Tahun 2000-2002”. Jurnal Sosio Economi 7, Edisi November 2004.

Noer, Azam Achsani. (2000) Mencermati Kejatuhan Indeks Dow Jones:Akankah Indeks BEJ Ikut Terseret? Postdam: University of Potsdam.

Perotti,E.C.,and Oijen, P. (2001) "Privatization, Political Risk and Stock Market Development in Emerging Economies". Journal of International Money and Finance, Vol.20,pp.43-69.

Santoso, Singgih. (2000) Latihan SPSS Statistik Parametrik. Jakarta: PT Elex Media Computindo.

Scott, L David. (2009) The American Heritage Dictionary of Business Terms. New Jersey: Houghton Mifflin Harcourt.

Siamat, Dahlan (2005) Manajemen Lembaga Keuangan. Jakarta:FE UI.

Sergio, L. Smulke. Pablo, Zaido. Marina, Halac. (2005) "Financial Globalization, Crisis and Contagion". International Economic Journal, Vol. 10, No. 2, Summer, pp. 121130.

Sugiyono. (2006) Metode Penelitian Bisnis. Cetakan Ketujuh. Bandung: Alfabeta.

Tandelilin,Eduardus.(2009).Portofolio dan Investasi:Teori dan Aplikasi.Edisi Pertama.Jakarta: Kanisius.

UU Pasar Modal No. 8 Tahun 1995

Wondabio, Ludovicus Sensi. (2005) "Analisa Hubungan Index Harga Saham Gabungan (IHSG) Jakarta (JSX), London (FTSE), Tokyo (Nikkei) dan Singapura (Ssi)”. Jurnal Simposium Nasional Akuntansi, 9 Padang K-AKPM7. 